\title{
LICHENS AS BIO INDICATOR FOR AIR POLLUTION AND THEIR RELEVANCY IN POKHARA, NEPAL
}

\author{
Kalyan Panta ${ }^{*}$ \\ ${ }^{1}$ Department of Botany, Prithivi Narayan Campus, Tribhuvan University, Pokhara, Nepal \\ *For correspondence: kalyanpanta@yahoo.com
}

\begin{abstract}
The use of naturally occuring lichens as a bioindicator to assess the health of environment is a well proved potential strategy to monitor any habitat without device/ instruments. The article clearly revealed that the quality of air pollution has been a major problems in city area and suburban areas. In this case, the lichens could be used as reliable indicators to trace the air polluted sites and It could be useful to combact the decreasing anthropogenic disturbances such as vehicular emission, constrution of civil works, etc. The essence of these studies provide an understanding of envioronmental impacts and can follow the policy makers to protect the Lichen flora and air pollution realated problems.
\end{abstract}

Key words: lichen. biomonitoring, hygrophytic, bioindicators, environmental health

\section{INTRODUCTION}

A Greek Philosopher Theophrastus, the father of Botany, coined the word 'Lichen' in 300 BC is still commonly in use among all countries (Hackworth and Hill, 1984). The lichens are made up of ascomycetes fungus, mycobiont and green and/or blue green alga, phycobiont (Hackworth and Hill, 1984; Hale, 1979). These are the symbionts between these mycobint and phycobiont that act a single lichen thallus, are highly valued ecological bio indicators for environmental stresses like air quality and climate change (Jovan, 2008).

Lichens do not have roots, stems and leaves however they get nutrients from the atmosphere and the thalli accumulate different suspended particles. The substances associated with thallus from surroundings by ions exchange, extracellular electrolyte absorption, hydrolysis and intracellular uptake and shows varying sensitivity to metals. So, these are the most studied bio indicators of air quality (Awasthi, 1991; Begum et al., 2008). Lichens demonstrate their utility as monitoring of air quality, the restults obtained from different habitats such as volcanos, glacier retreats (Nylander, 1866).

Yemets et al (2014) quantified and assesed the dispersal airborne traffic-related elemental pollutants $\mathrm{Ca}, \mathrm{Mg}$, $\mathrm{Fe}, \mathrm{Na}$, , $\mathrm{Zn}, \mathrm{Al}, \mathrm{Ba}, \mathrm{Cu}, \mathrm{V}$, $\mathrm{Cr}, \mathrm{Ni}, \mathrm{Co}, \mathrm{Sn}, \mathrm{As}, \mathrm{Mo}$ in southern Norway and found heavy metal accumulation that increased from foliose to fruticose lichens in the order: $P$. sulcata $>$ L. pulmonaria $>R$. farinacea $X \mathrm{U}$. dasopoga. They also established the protocol for this type of experiment. Lodha (2013) also experimented the lichen species for monitoring air pollution. The diversity of lichen with their potentiality of detecting environmental health have been used around the world now since the last ten decades (Hauck, 2009). The main phytotoxin gas present in Lichen thallus have been used to monitor the effects of atmospheric $\mathrm{So}_{2}$ since for decades in in urban and industrial areas (Hawksworth and Rose, 1970).

In Europe and North America, the reduction of $\mathrm{So}_{2}$ emission, $\mathrm{NH}_{3}$ and $\mathrm{NO}_{2}$ have become main airborne pollutants as a problem from lichens (Davies et al., 2007). Not only this, the ability 
to cope with dry conditions (xerophytism) and ability of deposition of dust and nitrogen compounds (eutrophication tolerance) are often associated with lichens creates the problems of re $\square$ establishing normal antioxidant concentrations and enzymatic activity during re $\square$ hydration, (Hauck and Wirth, 2010) while hygrophytic ones suffer a more intense oxidative stress (Mayaba and Beckett, 2001). Hence the lichens show the efficient anti $\square$ oxidative mechanisms that allow xerophytic species to better survive long periods of adverse condition of dryness or of exposure to nitrogen and pollutants in general (Tretiach et al., 2012). Many research on lichens and air pollution has been done in northern hemisphere since over forty years and nowadays have been used as economical and long-term biomonitoring tools in many countries (Rindita and Koesmaryono, 2015). An urban settlement south east of Serbia without much large industry and traffic area, Dimitrovgrad has Candelariella, Evernia, Ochrolechia, Parmelia (sensitive lichens) Buelia, Lecanora, Lecidella and Physcia stellaris (less sensitive lichens) whereas Phaeophyscia orbicularis, Candelariella xanthostigma, Physcia adscendens, Physcia distorta, Phy. grisea and Xanthoria parietina were the most tolerant lichens (Stamenković, 2010).

In conclusion, lichens are sensitive to especially sulphur dioxide, nitrogen-containing pollutants, and acidic deposition, are the best understood till now. The pollutants emerging from roads and industries are being faced by all cities of the world due to urbanization, have also become victim to innocent people. Thus the quality of air is getting deteriorate all over the world. The same types of biomonitoring are essential developing countries like Nepal. In this context the relevancy of floristic patterns of lichens may be essential in Pokhara city to understand relation of lichens and air pollution.
Various types of lichens that have potentiality of detecting airborne pollutants could be achieved from the Pokhara valley, one of the tourist destination centre of the world.

\section{Lichens as bio indicators}

Normally foliose and fruticose lichens act as biomonitoring of the surroundings however, some crustose species are not in exception. The presence of fruticose lichens in any locality indicates the clean environmental areas. As the level of pollution increases the fruticose starts to disappear first, then foliaceous lichens and finally the crustose lichens remains in a polluted environment (Begum and Harikrishna, 2010). Hence the composition of lichen flora in the vicinity of an urban (residential, in industrialized, in semi urban forests and village) is the best suited to measure the air pollution.

The air quality based on lichens of the corresponding stations revealed the following results (Begam and Harikrishna, 2010)

\begin{tabular}{|l|l|l|}
\hline $\begin{array}{l}\text { Lichen } \\
\text { species }\end{array}$ & Air quality & Remarks \\
\hline $\begin{array}{l}\text { Very less } \\
\text { abundance } \\
\begin{array}{l}\text { Crustose } \\
\text { lichens }\end{array}\end{array}$ & Poor & $\begin{array}{l}\text { Industrial area } \\
\text { with heavy traffic } \\
\text { and Maximum } \\
\text { Heavy contents }\end{array}$ \\
\hline $\begin{array}{l}\text { Leafy and } \\
\text { Crustose } \\
\text { lichen }\end{array}$ & Moderate & $\begin{array}{l}\text { Anthropogenic } \\
\text { pollution and } \\
\text { heavy traffic }\end{array}$ \\
\hline $\begin{array}{l}\text { Foliose, leafy } \\
\text { and Crustose } \\
\text { lichens } \\
\text { present }\end{array}$ & Good air & $\begin{array}{l}\text { Nearly } \\
\text { maintained } \\
\text { residential area }\end{array}$ \\
\hline $\begin{array}{l}\text { Foliose } \\
\text { lichen Usnea } \\
\text { articulata }\end{array}$ & air clean & A National Park \\
\hline
\end{tabular}

The floristic studies on lichen collection protocol, voucher specimen requirements, identification procedure and database compilation all are 
essential baseline in the study area for judging future changes (Nash et. al., 1993). As the study area lies in microclimatic variation within a short distance in tropical region, the distribution of lichens may be different types. Not only this, lichens are influenced by physical and biological

Table 1: Lichens species as biomonitoring

\begin{tabular}{|c|c|c|c|c|c|}
\hline 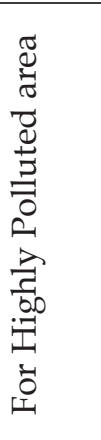 & $\begin{array}{l}1 . \\
2 . \\
3 . \\
4 . \\
5 . \\
6 . \\
7 . \\
8 . \\
9 .\end{array}$ & $\begin{array}{l}\text { Hypogymnia physodes } \\
\text { Xanthoria parietina } \\
\text { Lecanora dispersa } \\
\text { Diploicia canescens } \\
\text { Lepraria incana } \\
\text { Lecanora expallens } \\
\text { Lecanora conizaeoides } \\
\text { Cladonia macilenta } \\
\text { Buellia punctata }\end{array}$ & 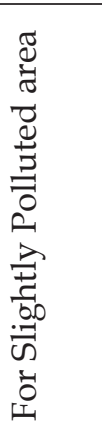 & $\begin{array}{l}1 . \\
2 . \\
3 . \\
4 . \\
5 . \\
6 . \\
7 . \\
8 . \\
9 .\end{array}$ & $\begin{array}{l}\text { Parmelia caperata } \\
\text { Graphis scripta } \\
\text { Bryoria fucescens } \\
\text { Physconia distorta } \\
\text { Opegrapha varia } \\
\text { Anaptychia ciliaris } \\
\text { Parmelia acetabulum } \\
\text { Buellia punctate } \\
\text { Physcia aipolia }\end{array}$ \\
\hline 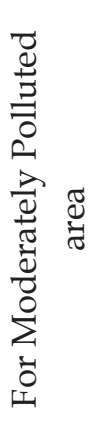 & $\begin{array}{l}1 . \\
2 . \\
3 . \\
4 . \\
5 . \\
6 . \\
7 . \\
8 . \\
9 .\end{array}$ & $\begin{array}{l}\text { Evernia prunastri } \\
\text { Foraminella ambigua } \\
\text { Lecanora chlarotera } \\
\text { Ramalina farinacea } \\
\text { Lecidella elaeochroma } \\
\text { Hypogymnia physodes } \\
\text { Parmelia glabratula } \\
\text { Parmelia saxatilis } \\
\text { Plastimatia glauca }\end{array}$ & 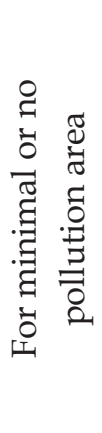 & $\begin{array}{l}1 . \\
2 . \\
3 . \\
4 . \\
5 . \\
6 . \\
7 . \\
8 .\end{array}$ & $\begin{array}{l}\text { Usnea subfloridana } \\
\text { Parmelia perlata } \\
\text { Degelia plumbea } \\
\text { Ramalina fraxinea } \\
\text { Teleoschistes flavicans } \\
\text { Lobaria pulmonaria } \\
\text { Lobaria scrobiculata } \\
\text { Pannaria rubiginosa }\end{array}$ \\
\hline
\end{tabular}

Air quality studies with bio indicators have not been well developed in Nepal. In the city of Pokhara, there are not permanent air pollutant measurements by equipment. Hence, it will develop an air quality biomonitoring system using lichen. Several studies have shown serious impacts on the growth and health of lichens resulting from factory and urban air pollution. Because some lichens are so sensitive, they are now being used to quickly and cheaply assess levels of air toxins in Europe and North America (https://www.gktoday.in). The research on lichens and air pollution has been done in north hemisphere countries since over forty years and significant progresses have also been in south east Thailand (Rindita and environments of variety of habitats. The growth survival also depends upon insolation, temperature, moisture, soils, chemistry and winds. The following are the best known lichens used as bio monitors (Lodha, 2013).

Koesmaryono, 2015) and other neighboring countries Furthermore, Vietnam has made better progress doing additional investigation on it (Jayalal et al, 2013). Lichens are widely used as long term and economical biomonitoring tools in many countries that exist in Pokhara valley. As a developing greenery and microclimate variability in Pokhara Metropolitan City.

\section{RELEVANCY OF LICHENS IN POKHARA}

World famous Pokhara Metropolitan City having high rate of tourist influx is still unknown regarding lichen investigation. The bio indication of air pollution by using neglected lower plant lichens has not been done 
in developing country like Nepal until now. Furthermore, we have not been able to make a little systematic survey in urban areas and are still far behind in comparison to other developed countries about its knowledge and uses. Hence, realizing the ecological significances in particular context of Nepal. It is desirable to undertake an inventory on airborne pollutants species of lichens in Pokhara Metropolitan City. The present study therefore, aims as to investigate the floristic distribution and bio indicators of airborne pollutants of lichens and is relatively easy to collect, preserve and analyze for pollutant related studies in future.

Pokhara, the capital of Gandaki Province, has registered a total of 184395 vehicles in the fiscal year 2074/75 (Govt. Nepal 2075). This number is increasing rapidly for the last few years. Pokhara has been a hub for both national and international tourists. Each day the atmospheric gasses of this clean city has been deteriorating. Thus an urgent step has to be taken to safe guard the future of this city. One of the easy ways is to monitor its airborne pollutants is an application of lichen species as bio monitor. Lichens can be a good tool to measure such airborne quality.

\section{REFERENCES}

Awasthi, D. D., (1991) A Key to the Microlichens of India, Nepal and Sri Lanka, Bibl. Lichenol. 40: 1-337.

Begum A. and S. Harikrishna (2010.) Monitoring Air pollution using lichens species in South Bangalore, Karnataka, International Journal of Chemtech Research CODEN (USA): IJCRGG. 2(1): 255-260.

Begum, A., S. Harikrishna, K. Veen and I. Khan (2008). Lichens are indicators of Heavy metal pollution, http/ Secindia. Wordpress.com, Published in Pollution News, Issue 4, Air Quality Bioindicator Using the Population of Epiphytic Macrolichens in Bogor City,
West Java

Begum, A. and S Harikrishna (2010) Monitoring Air pollution using lichens species in South Bangalore, Karnataka. International Journal of Chem Tech Research CODEN (USA): IJCRGG. 2 (1): 255-260.

Davies, L., Bates, J., Bell, J., James, P. \& Purvis, O. (2007) Diversity and sensitivity of epiphytes to oxides of nitrogen in London. Environmental Pollution. 146: 299-310.

Hackworth, D. L and D. J. Hill (1984). The lichenforming fungi. Blackie and Son Limited; New York, NY

Hale, M. E. (1979). How to know the lichens? 2nd edition. WCB McGraw-Hill; Madison, WI.

Hauck, M. and V. Wirth (2010). Preference of lichens for shady habitats is correlated with intolerance to high nitrogen levels. The Lichenologist. 42: 475-484.

Hauck, M. (2009). Global warming and alternative causes of decline in artic -alpine and borel-montane lichens in NorthWestern Central Europe. Global Change Biology. 15: 2653-2661.

Hawksworth, D.L. and F. Rose (1970). Qualitative scale for estimating Sulphur dioxide air pollution in England and Wales using epiphytic lichens. Nature. 227: 145148.

Jayalal U, Aptroot A, Nguyen TT, Dzung NA, Joshi S, Oh SO, Hur JS. 2013. Further additions to the macrolichen mycota of Vietnam. Mycotaxon. 124:51-59. Http:// dx.doi. Org/10.5248/124.51

Jovan, S. (2008). Lichen bioindication of biodiversity, air quality, and climate: baseline results from monitoring in Washington, Oregon, and California. Gen. Tech. Rep. PNW-GTR-737.

Lodha A.S. (2013). Evaluation of various Lichen species for monitoring pollution, Current Botany.4(3): 63-66, Available Online: http:/ / currentbotany.org 
Mayaba, N. and R.P. Beckett (2001). The effect of desiccation on the activities of antioxidant enzymes in lichens from habitats of contrasting water status. Symbiosis. 31: 113-121.

Nash III, T. H., C.M. Wetmore, W. Anderson, C. Bratt, W.C. Denison, S. Eversman, C. Murray, L.S. Clair (1993). Floristics Lichens as Bioindicator of Air Quality, Rocky Mountain Forest and Range Experiment Station. U.S. Dept, of Agriculture, Fort Collins, Colorado. 6-15.

Nylander, W. (1866). Les lichens du Jardin de Luxembourg. Bulletin de la Société Botanique de France. 13: 364-372.

Rindita, S.L. and Y. Koesmaryono (2015) Air Quality Bioindicator Using the Population of Epiphytic Macrolichens in Bogor City, West Java. Hyati journal of Biosciences. 22(1): 53-59. Available online at: http://journal. ipb.ac.id/index.php/hayati
Stamenković S., M., Cvijan and M. arandjelović (2010) Lichens as bio indicators of air quality in dimitrovgrad (south-eastern serbia). Arch. Biol. Sci., Belgrade 62 (3): 643-648.

Tretiach, M., S. Pavanetto, E. Pittao, L. Sanita di Toppi, and M. Piccotto (2012). Water availability modifies tolerance to photooxidative pollutants in transplants of the lichen Flavoparmelia caperata. Oecologia. 168: 589-599.

Yemets, O. A., K. A. Solhaug, and Y. Gauslaa (2014). Spatial dispersal of airborne pollutants and their effects on growth and viability of lichen transplants along a rural highway in Norway. The Lichenologist. 46(6): 809-823. 